\title{
Reflections on Stalin and the Holodomor
}

\author{
Françoise Thom
}

Paris-Sorbonne University (Paris IV)

\begin{abstract}
The mechanisms and the chronology of the great crimes committed by totalitarian regimes are now well documented. While they may explain the mechanics of these events, they do not always explain why they transpired. The implementation of Stalin's policy of collectivization and de-kulakization relied on dissimulation. Moreover, the pace of collectivization was justified by external threats, initially from Great Britain and Poland, and later extending to Japan. This made possible the branding of any political adversary as a traitor. As long as Stalin faced organized political opposition, he was unable to launch any maximal policies. After the defeat of Trotsky in December 1927 he was able to create crisis situations that ultimately furthered his own power. The offensive he unleashed against the peasants became a means of reinforcing his increasing dictatorship. The collectivization campaign employed the rational argument that the backward countryside needs to modernize production. Its ultimate aim, however, was the crushing of an independent peasantry. There are enlightening comparisons that can be made between collectivization in China and the USSR, which are explored in this essay. The resistance to collectivization was particularly strong amongst Ukrainians. Stalin, who had long regarded the national question as inseparable from the peasant question, deliberately chose mass starvation to break resistance to his will. The history of these events was for a long time shrouded in great secrecy until it began being discussed by Western scholars, becoming a matter of considerable debate between the "totalitarian" and "revisionist" schools of Soviet historiography.
\end{abstract}

Keyword: Holodomor, Collectivization, China, USSR, Peasantry, Starvation

"Devastation as a principle of government! This is unprecedented in history..."

P. A. Valuev (1865) ${ }^{1}$

$\mathbf{T}$ he mechanisms and the chronological sequence of the great crimes committed by totalitarian regimes are now well documented. But this does not mean that the mystery of those moments of criminal folly engulfing a whole society is solved. We see links in the chain of events, we know by what arguments decisions were rationalized, and we can name

${ }^{1}$ Qtd. in Getmanskii 43. 
those responsible for the crimes. But ultimately a question remains: how can one explain that the instinct of self-preservation of a whole society has been disconnected, that plain common sense seems to have deserted the ruling group and those who are ruled, that elementary moral principles cease to exist? How can the leader impose a spiral of destruction and terror on his often-reluctant followers? Why does the ruling group accept to implement policies whose disastrous consequences it understands? Those questions apply to the Soviet Union under Stalin as well as Nazi Germany or Maoist China.

First we will try to understand how Stalin imposed the policy of collectivization and de-kulakization on the Politburo and the Communist apparatus. His tactic relies on dissimulation. For many Communists Lenin's New Economic Policy (NEP) had been a forced and temporary compromise with the peasant masses. But the relative economic independence of the peasants was considered a potential threat to the survival of the Bolshevik regime. Apparently Stalin could easily have persuaded his colleagues that Bolshevik rule should be imposed on the peasants as it was on the rest of Soviet society. Nevertheless he chose to take his Politburo colleagues by surprise by hiding his designs until the last minute. In 1926, when he was still in need of "rightists" to defeat the Trotskyists, he criticized Evgenii Preobrazhenskii for advocating a policy towards the Soviet peasantry that was equivalent to the exploitation of the colonies by capitalist countries and for wanting to ensure "primitive socialist accumulation" at the expense of peasants" (Souvarine 364). On 16 February 1928, he wrote in Pravda: "The kulak was enriched more than others..." To this he added, "The NEP is the foundation of our economy and will remain so for a long time." At the July 1928 Plenum of the All-Union Communist Party (Bolshevik) (AUCP[B]), he proclaimed: "Our policy is not to stir up the class struggle... We have no interest in the class struggle taking the form of a civil war." Stalin had so well hidden his intentions that in early September 1929, Grigorii Ordzhonikidze, one of his closest associates, still maintained that total collectivization would take "years and years" (Conquest 118).

The ruthless pace of collectivization would have been difficult to justify had Stalin had not whipped up a huge war scare: tense relations with Great Britain after the breaking off of diplomatic relations following the Arcos Affair in May 1927, and the murder of Petr Voikov, the Soviet representative in Poland, heralded by the Kremlin as a new Sarajevo, furnished Stalin a pretext to depict the USSR as a country surrounded by enemies intent on unleashing war on the socialist fatherland. This, in turn, allowed any political adversary to be branded as a traitor. Already in April 1927 at the Sixteenth Party Conference Stalin tests the waters in this regard, stating "It is impossible to develop a real struggle against class 
enemies if we have their agents in our ranks." Dissidents are labelled as traitors. This background of hysterical paranoia is one of the factors explaining the paralysis of society in advance of the total offensive of the Stalinist group.

In December 1927, Leon Trotsky and Grigorii Zinov'ev are expelled from the Politburo. As long as an organized opposition existed in the USSR, Stalin could not launch potentially disastrous policies, because his adversaries could use fiascos against him. But after the defeat of Trotsky and his allies, Stalin knows that he now can take risks. In January 1928, the first "extraordinary measures" against the peasants are adopted. Already in the summer of 1928 the catastrophic consequences of this policy were obvious. Stalin does not back down. In fact, he resumes political manoeuvres. Whether against individuals or groups, Stalin's offensives are always gradual, sometimes spread over a very long time. A wave is followed by a retreat and then a new wave going further. There is a kind of inexorable crescendo that culminates with Stalin's victory. After the first offensive against the "rightists" in the spring of 1928, when "extraordinary measures" caused shortages and a powerful wave of discontent in the country, Stalin is forced to retreat. At the Plenum of 4-12 July 1928, he pretends to take into account the arguments of the "rightists." He announces that "extraordinary measures" are temporarily suspended and stresses that those who want to implement them on a permanent basis are wrong (Stalin, "Ob industrializatsii"). Of course, all these concessions were ephemeral and Stalin soon resumed the offensive. In the spring of 1929 the "rightists" were routed. The same scenario of temporary concessions and further radicalization was repeated in 1930 and the following years.

In February-May 1930, Ukraine and Belarus were shaken by peasant revolts because of collectivization, so that at the beginning of 1930 the Soviet leaders feared that peasants would refuse to sow. At the same time Stalin was worried about the possibility of a joint invasion of the Soviet Union by Poland and Japan (Ken and Rupasov 71). For those reasons he pretended to offer a truce to the peasants in March, when he wrote his famous article "Dizzy with Success" (March 2) and momentarily suspended collectivization. This blowing hot and cold, this alternation of hope and certainty of the worst, of radical ultra-leftist policies and unexpected limited relaxation, this succession of "abuses" and denouncing "abuses," with exemplary punishment of the culprits, explains why resistance fails to crystallize. The French historian Alphonse Aulard wrote about Robespierre: "He weighs on minds like the tyranny of uncertainty" (Furet and Ozouf 257). This fully applies to Stalin as well.

From this time forward, as in the early years of Bolshevik rule, any setback is used as a pretext for tightening the screws. The crisis unleashed 
by the offensive against the peasants becomes a means of reinforcing a dictatorship. Chronic crisis and selective starvation become the way to absolute power. The appalling consequences of earlier measures lead to the adoption of even worse, more radical policies. Combined with hysterical propaganda about the danger of foreign intervention, the critical situation provides a pretext to silence the opposition. Thus, the severity of the crisis unleashed by Stalin, far from diminishing his power, strengthens his position. The horrendous situation gives him a way to blackmail possible opponents: who if not a traitor would cause a split when the country is on the brink of an abyss? Nikolai Bukharin's case illustrates the success of this tactic. In August 1928, he wrote to Stalin: "I already told you I will not fight you and I do not want to fight. I know only too well what a fight can cost, especially in the serious situation in which the country and the Party find themselves" (Kvashonkin 40). In his speech to the Politburo on 30 January 1929 Bukharin does not mince words in criticizing the peasant policy of Stalin, but he concludes with these words: "The challenges the country faces are so immense that it would be a truly criminal loss of strength and time to unleash a fight at the top" (Danilov vol. 1, 528)-before asking to be released from his duties.

It should also be noted that Stalin took great care not to confront all social groups at the same time. As in foreign policy, his purpose has always been to avoid the building-up of a united front against him. Thus, in June 1931, when he was planning to inflict the coup de grâce to the peasantry, Stalin ended the process initiated in 1928 by the Shakhty trial that sparked the hunt for "bourgeois specialists." He suddenly discovered that the harassment of experts and egalitarianism was harmful, that an engineer of the old school was not necessarily a saboteur.

Finally we should take into account Stalin's colossal hypocrisy, a permanent feature of totalitarian regimes. Collectivization was first trumpeted by propaganda as a policy of "social justice" in favor of the poor peasants. It is only in 1932 that Stalin drops the mask, and it becomes clear that the Party has unleashed total war against the peasantry as a whole. In his memoirs Kandid Charkviani, who will be the first secretary of Georgia from 1938 to 1952, gives us a striking example of Stalin's hypocrisy.

In 1931 Stalin was on vacation in Georgia. He summoned the leader of the Georgian Communist Party, Samson Mamulia, and the Prime Minister Lado (aka Levan) Sukhishvili. Stalin asked Mamulia: "How are the collective farms?" "The situation is bad, Comrade Stalin," replied Mamulia. "Some kolkhozes are unraveling. We have to arm the Communists to neutralize hostile elements and keep the peasants in collective farms." Stalin exploded: "You claim that the peasants should be herded into collective farms by the 
force of arms! What about voluntary adhesion to the kolkhoz, what about the interests of poor and middle peasants???" (Charkviani 452)

Thus, Stalin turned against the very people who had applied his policy, playing the role of the righter of wrongs.

This mad and criminal policy is camouflaged by seemingly rational arguments. Collectivization is justified by the need to urbanize the backward countryside, to modernize production. Stalin is fighting against barbarism by barbaric but necessary methods. He wants "giant collective farms" through which Soviet agriculture will have a rational, scientific basis. The tractor will displace the horse, and an army of agronomists will stimulate the development of production based on the collective effort. This technocratic propaganda will even be accepted and spread by some foreign observers eager to minimize the horrors of de-kulakization and to find excuses for Stalin.

As a matter of fact, Stalin was pursuing rational aims through this policy: he was reinforcing his power. In launching collectivization Stalin intended to crush not only the peasantry. He had also begun the process, which will to be completed in 1938-39, of the liquidation of the old Bolshevik guard and the radical renewal of the Party from the bottom up. At the Plenum of July 1928 (mentioned above) Stalin voiced his belief that the current difficulties would result ultimately in a strengthening of the Bolshevik ranks. Forcing the local Bolshevik leaders to implement collectivization was a sure means to discredit and destroy them in the eyes of the people: thus it was the first step of Stalin's policy of eliminating the older generation of Bolsheviks and replacing them with young careerists devoted to him. The example of collectivization in Transcaucasia is significant from this point of view. Stalin used collectivization as a pretext to begin the dismantlement of the Ordzhonikidze clan. From 1929 on, Beria, then chief of the Georgian GPU, wrote scathing reports on the disasters caused by this policy, laying the blame on the leading Communists, Lela Kartvelishvili or Mamulia, protégés of Ordzhonikidze. Thus in March 1929, after the crushing of an uprising in Adzharia, Beria wrote: "Now that the attempt to revolt is liquidated, we have to analyze its causes. For us there is no doubt that they are to be found in certain measures adopted by the Party organizations and the organizations of Soviets, which are isolated from the masses and do not take into account their state of mind..." (cited in Sokolov 40-47). Stalin was so enchanted by Beria's competent denouncing of the Transcaucasian Bolsheviks that he promoted him at the head of the Georgian Party in 1931 and of the Party in Transcaucasia in 1932, destroying Ordzhonikidze's regional power base (Thom 27-35). He was so 
pleased with Beria that he accepted lowering the grain requirements for Beria's fiefdom.

Another obvious illustration of this strategy is the replacement of the "rightist" Aleksei Rykov as the head of the government by the reliable Viacheslav Molotov, signifying the takeover of the government by the Stalinist faction. On 13 September 1930 Stalin wrote to Molotov: "The council of the deputies of the Chairman of Sovnarkom has a tendency to become the headquarters of the opposition to the Central Committee" (Khlevniuk, Forgues and Werth 52). The solution was to appoint the loyal Molotov as chairman of the Sovnarkom. On December 19, Rykov was fired: "We finally have a perfect unity at the top of the state and Party, which will strengthen our power." "The leaders of the Party and the Soviet apparatus will form a single fist," said the head of the Communist Party (Bolshevik) of Ukraine, Stanislav Kosior, who took the formal initiative of proposing this measure (Danilov vol. 2, 772). In late December the merger of state and Party at the highest level was accomplished.

Throughout his war against the peasantry, Stalin will make successive purges in the Party, removing, layer by layer and at all levels, those who are suspected of pity for the kulak, those who had floundered. This very special selection will create a party formed by ruthless individuals desperate to please the Leader. This aspect of collectivization as a "pedagogy" for the Party is clear in a speech by Molotov on 18 March 1930, in which he accused the local authorities of the Party for not having taken a sufficiently active role in de-kulakization, preferring to rely on the OGPU.

A comparison between collectivization in China and in the USSR is very enlightening. The Communist systems relied on total destruction of political institutions. For this reason, having reached the top of the Party apparatus, the ruling despot has only to fear the Communist establishment, the sole limit on his power. The history of both Stalin's and Mao's reign can be interpreted as the history of their struggle against the Party establishment. In the early 1950s Mao wanted to abandon the policy of "new democracy," which allowed the Communists to take power on a relatively moderate program, and to begin immediately the transition towards "socialism." Mao's closest colleagues, such as Liu Shaoqi, were opposed to this new orientation. Mao imposed his views in the summer of 1953, but already in 1955 the disastrous effects of Mao's first collectivization were obvious. In the spring of 1956 Liu and Zhou Enlai concluded an alliance and forced Mao to stop hasty collectivization. This resistance of top Party leaders and the solidarity they had displayed among themselves infuriated Mao. He chose extreme radicalization to defeat them: in 1957-58 he launched the Great Leap Forward, which resulted in 35 million deaths. The campaign for the establishing of "people's communes" was unleashed at the same time Mao 
provoked huge international tensions by bombing the Taiwanese islands of Quemoy and Matsu in August 1958. The ensuing disaster lead to a reaction by the Party establishment: in January 1962 Mao's policy is criticised by his closest associates: Liu, Zhou and Deng Xiaoping. Mao is sidelined in the Party leadership. In response, Mao decides to destroy the existing Party and to replace it from top to bottom. He builds his faction with the support of the security apparatus and the military, controlled by Lin Biao (then his closest associate), and launches the Cultural Revolution in 1966, which leads China to anarchy and civil war. Thus Mao turned to extreme radicalism to defeat his colleagues (this is the central premise of Domenach).

The analogy with Stalin's tactic is obvious. As I have shown, Stalin's aim was to use collectivization to proceed to his own revolution and to get rid of the old Bolshevik guard; as in China's case, revolutionary maximalism was a weapon aimed at the Party establishment. Contrary to Mao, Stalin's power was apparently unscathed after the tragedy of collectivization. Nevertheless, historians have rightly pointed out that the great purges of 1937-38 were an aftermath of collectivization. The trauma left by this experience in the Party was deep: the mysterious Kremlin affair in 1935 which led to the demise of the Old Bolshevik Avel Enukidze and prepared the ground for the later purges reflects the turmoil in the higher circles of the Kremlin. Like Mao, Stalin decided to build a new Party in 1936-37. During the great purges, the accusation that a person disapproved of collectivization crops up often. In his famous speech at the Military Council on 2 June 1937 Stalin heaped scorn on Enukidze: "Can you imagine, this bastard Enukidze felt pity for the peasants. And since he can play the simpleton, this beanpole, people believed him..." (Stalin 214-35). After his arrest, Mikhail Frinovskii, Ezhov's deputy, confessed that Efim Evdokimov, the former chief of the secret operational department of the OGPU, told him at the time that he thought the liquidation of kulaks was wrong and that he did not believe in the success of this policy, being convinced that it would ruin the villages and destroy agriculture (Khaustov et al 35). And again, in 1952, a few months before his death, Stalin adopted an ultra-leftist program as a preparation for the elimination of the main group of the Politburo. Ultimately, both Stalin and Mao failed to defeat the Party establishment, because by extreme policies they undermined their own faction.

For Stalin, reinforcing his personal power and reinforcing the power of the Soviet state amounted to one the same thing. Here we find his second goal for launching collectivization and organizing famine in Ukraine. In 1928, Stalin decides to transform the Soviet state into a war machine. Part of the military-industrial complex had to be built in Siberia for security reasons. Stalin needed an enslaved workforce to implement this ambitious 
plan. He knew that the promise of turning the USSR into a great power would bring him the support of the Russian people in spite of all the hardships and repressions. But the non-Russian peoples of the Soviet empire were less likely to support such a venture.

Moreover, among non-Russians resistance to collectivization was especially strong. In the spring of 1930, uprisings against collectivization were numerous in Ukraine, in the North Caucasus, the Cossack regions, and in Azerbaijan. In Stalin's mind the national question was always inseparable from the peasant question. In 1925 he wrote: "The national question is essentially that of the peasantry" (Mace 79). Destroying the Ukrainian nation, which Stalin suspected would side with Poland in the event of a conflict between the USSR and its Western neighbours (Martin 327), became a priority. Stalin chose starvation deliberately as a means to attain this purpose. That Ukraine was specifically targeted is evident clearly in the different treatment that Transcaucasia (after the sacking of its old Bolsheviks) and Ukraine received. In a letter to Kaganovich on 17 August 1931, Stalin writes: "I understand now that Kartvelishvili [an old Georgian Bolshevik protected by Ordzhonikidze] and the secretariat of the Georgian Central Committee, by their mad policy of requisitioning grain, have caused famine in many parts of western Georgia. They do not understand that the methods of requisitions, necessary in the Ukrainian grain regions [author's emphasis] are harmful in areas that are not producing grain and have no industrial proletariat.... We must accelerate the import of wheat, and immediately. Otherwise we will have riots, although the problem of grain supply is already solved here" (Khlevniuk et al 51).

Hysteria about the so-called aggressive Polish designs against the USSR was used to justify the harsh treatment inflicted on Ukraine. A genocidal policy is always linked to a view of a world under siege: propaganda presents the eradication of the targeted group as a prophylactic measure. The hypocrisy of Stalin's propaganda appears blatant when we take into account that a Soviet-Polish non-aggression pact was signed in July 1932. Moreover, the USSR's position on the international stage was being reinforced in other realms. In June 1932, Stalin learned from his spies that the Japanese had decided to avoid confrontation with the USSR. Additionally, Turkey—following destabilization in Transcaucasia because of peasant uprisings-promised (in a secret protocol to the Soviet-Turkish treaty of November 30,1931) to deport some of its most active political émigrés and to forbid anti-Soviet activity on Turkish territory (Balaev 236). Stalin's worst genocidal measures (i.e., the decision to confiscate seed grain) were introduced in Ukraine in December 1932. And in January 1933 starving peasants were ordered to stay in their villages and troops were deployed to prevent them from fleeing. 
The Ukrainian elites were also targeted by Stalin's offensive. The joint plenum of the Central Committee and Central Executive Committee of the All-Union Communist Party (Bolsheviks), AUCP(B), held on 11 January 1933, launched a purge of the leadership of the Communist Party of Ukraine (CPU) and the end of the "Ukrainization" policy set up under Lenin. Stalin blamed the failure of the collective farms there on sabotage by "Petliurites," supporters of the Ukrainian independence efforts in 1917-20 and then later in exile. Stalin depicted the exodus of hungry peasants as a Polish plot to discredit collectivization. After this Plenum the leadership of the CPU is replaced and 600 political departments of Machine-Tractor Stations (MTS) are sent to Ukraine. "Dens of counter-revolutionaries" are unmasked in scientific and academic organizations.

As with the Jewish genocide organized by Himmler, the starvation of Ukraine was surrounded by the deepest secrecy. Vsevolod Balyts'kyi, chief of the state security service in Ukraine, writing to Genrikh Iagoda, chief of the All-Union OGPU, explained on 22 March 1933 that he requested his subordinates not to circulate written reports by the OGPU on the famine among Party secretaries. He asked to be personally informed by his subordinates through oral reports (Werth and Berelowitch 279-80).

The contemporary historiography of the Soviet Union has been shaped by a debate between the so-called "totalitarians" and the "revisionists." The totalitarian school, represented by such authors as Robert Conquest and Adam Ulam, emphasizes the role of ideology and terror in the Communist regime. It also stresses the role of Stalin as a decisive factor. The revisionists, which include Sheila Fitzpatrick and Jerry Hough, among others, focus more on society and a "structuralist" approach. Documents made available after the collapse of the Soviet Union tend to vindicate the totalitarian interpretation. They prove that Stalin and the Soviet leadership were fully informed about the famine in Ukraine, and that Stalin deliberately decided to starve the Ukrainian population for ideological reasons: peasants, especially Ukrainian ones, were too attached to private property and individual work, too contaminated by Western influence. Documents also show that local authorities were constantly trying to mitigate the hard line imposed by Stalin; this contrary to the theories of the revisionists who believed in "cumulative radicalization," that is, an amplifying role of the local bureaucracy, leading to total disaster. As a matter of fact, Stalin was constantly obliged do dispatch his closest associates to the provinces in order to impose his murderous policy on local Communists (as he did later during the Great Purges).

All revolutionary regimes strive to implement irreversible measures. In Jacobin France committing regicide, executing King Louis XVI, and later annexing Belgium, was perceived as crossing the Rubicon. Such acts 
isolated France from Europe, making total war inevitable and consolidated the revolutionary dictatorship. In the USSR the collectivization campaign and the ensuing Holodomor was such a Rubicon as well, with a similar goal of isolating the socialist fatherland by depopulating the borderlands. In Nazi Germany the "final solution" chained the German people to the sinking Hitler regime. Strikingly, the same expressions crop up in the justification of both the Nazi and Soviet crimes. According to the secretary of the Moscow Party organization, Karl Bauman, eradicating capitalism definitively in the countryside meant, "blow[ing] up the bridges so there is no way back [author's emphasis]." 2 Goebbels, having been informed about the "Final Solution," writes in his Journal on 2 March 1943: "We have gone so far, especially in the Jewish question, that it is no longer possible to go back now. And it's better that way. A movement and a people who have cut the bridges behind them fight more resolutely [author's emphasis] than those who still have the possibility of going back" (Goebbels 78-79). On 14 November 1943 he noted, "[having] blown up the bridges ... We shall enter into history either as the greatest statesmen or the greatest criminals of all times."

We have tried to show in this paper how Stalin had singlehandedly imposed his calamitous and criminal line on unenthusiastic followers and on resisting masses. We have seen that, as in Nazi Germany and later in Mao's China, radical nihilist policies were camouflaged by the stated ambition to build a great autarchic conquering empire. But ultimately we still do not understand how a dictator can lead a whole people to selfdestruction. The mystery remains.

Under the influence of social sciences, contemporary history tends to place emphasis on impersonal processes, on bureaucratic mechanisms, on mind-sets, on economic factors. This reflects the condition of contemporary humanity, which feels overwhelmed by forces it does not control, such as globalization, international finance, multinationals and the like. Reflection on totalitarian systems, paradoxically, should lead us to a more optimistic worldview: individual choices, individual actions count. Even more so: they are the main driving force. This means that moral categories, good and evil, are still relevant. Of course this can be shocking to our modern "nonjudgmental" approach. The historian seeks to find the causes of human behaviour, to bestow intelligibility on the haphazard chaos of past events. In the chains of determinism he brings to light, he always stumbles on a simple truth: ultimately man is free. The calamities of the twentieth century show that in our mass societies the will of an individual is more decisive

2 See "Memorandum of 14 December 1929" (Danilov, vol. 2, 38). 
than ever, especially when this individual is driven by evil coupled to a passion for absolute power. Economic factors, bureaucratic intricacies, inertia of traditions weigh little when confronted with such a dynamic personality. Failure to understand this by the international community has made it blind to the dangers of such hostile modern despotic systems and explains its inability to cope with them in time.

\section{Works Cited}

Balaev, Aiyn. Mamed Emin Rasulzade (1884-1955). Moscow: Flinta, 2009. Print. Charkviani, K. Gantsdili da naazrevi. Tbilisi: Merani, 2004. Print.

Conquest, Robert. Sanglantes moissons: La collectivisation des terres en URSS. Paris: Bouquin, 1995. Print.

Danilov, V. et al, eds. Tragediia sovetskoi derevni. Kollektivizatsiia i raskulachivanie. Dokumenty i materialy v 5 tomakh, 1927-1939. Moscow: Rosspen, 1999. Print.

Domenach, Jean-Luc. Mao, sa cour et ses complots: derrière les Murs rouges. Paris: Fayard, 2012. Print.

Furet, François, and Mona Ozouf. Dictionnaire critique de la révolution française: Acteurs. Paris: Flammarion, 1992. Print.

Getmanskii, A. E. "Politika Rossii v pol'skom voprose (60-e gody XIX veka).” Voprosy istorii 5 (2004): 24-45. Print.

Goebbels, Joseph, and Pierre Ayçoberry. Journal, 1943-1945. Paris: Tallandier, 2005. Print.

Ken, Oleg, and Aleksandr Rupasov. Zapadnoe pogranichn'e: Politburo TsK VKP(b) $i$ otnoshenia SSSR s zapadnymi sosednimi gosudarstvami, 1928-1934. Moscow: Algoritm, 2014. Print.

Khaustov, V. N. et al., eds. Lubianka: Stalin i NKVD-NKGD-GUKR "Smersh": 1939-mart 1946: Moscow: Materik, 2006. Print.

Khlevniuk, O. V. et al., eds. Stalin i Kaganovich: Perepiska 1931-1936 gg. Moscow: Rosspen, 2001. Print.

Khlevniuk, O. V., Pierre Forgues, and Nicolas Werth. Le cercle du Kremlin: Staline et le Bureau politique dans les années 30: Les jeux du pouvoir. Paris: Éditions du Seuil, 1996. Print.

Kvashonkin, A. V. et al., eds. Sovetskoe rukovodstvo. Perepiska 1928-1941. Moscow: Rosspen, 1999. Print.

Mace, James E. "Soviet Man-Made Famine in Ukraine." Century of Genocide. Ed. S. Totten, W. Parsons, I. Charny. New York: Garland Publishing, 1995. 97-137. Print.

Martin, Terry. The Affirmative Action Empire: Nations and Nationalism in the Soviet Union, 1923-1939. Ithaca and London: Cornell UP, 2001. Print.

Sokolov, Boris. Beria: Sud'ba vsesil'nogo narkoma. Moscow: Veche, 2003. Print.

Souvarine, Boris. Staline: Aperçu historique du bolchévisme. Paris: Editions G. Lebovici, 1985. Print. 
Stalin, Iosif. "Ob industrializatsii i khlebnoi probleme." Polnoe sobranie sochinenii. Vol. 11. n.d., n.p. Iosif Vissarionovich Stalin. Sochineniia. Web. 24 June 2014. <http://www.petrograd.biz/stalin/11-18.php>

Stalin, I. Sochineniia. Vol. 14. Moscow: Pisatel', 1997. Print.

Thom, F. Beria, le Janus du Kremlin. Paris: Cerf, 2013. Print.

Werth, Nicolas, and Alexis Berelowitch. L'État soviétique contre les paysans. Rapports secrets de la police politique (Tcheka, GPR, NKVD), 1918-1939. Paris: Tallandier, 2011. Print. 